\title{
Asthma, wheezing, and school absence in primary schools
}

\author{
R A HILL, P J STANDEN, AND A E TATTERSFIELD
}

Respiratory Medicine Unit, City Hospital, Nottingham

SUmmaRY The prevalence of wheezing, 'asthma', treatment for 'asthma', and school absence as a result of wheezing in Nottingham was calculated from a questionnaire survey of parents of 4750 children in a random sample of primary schools. A response was achieved for $3805(80 \%)$ children of whom $438(11.5 \%)$ had had episodes of wheezing in the last year and $224(5.9 \%)$ had been diagnosed as having asthma. Asthma treatment had been prescribed for $251(6 \cdot 6 \%)$ of all children, two thirds of all the children receiving drugs. Two hundred and sixty five $(7 \%)$ children had lost time from school because of wheezing (median loss of seven days). Of the 64 children losing more than 10 days, $45(70 \%)$ were not taking any drugs, or taking only $\beta$ agonists.

The prevalence of wheezing found by this survey was comparable with that in similarly designed surveys, though the proportion of children diagnosed as having asthma was higher. Though doctors may now diagnose asthma more readily wheezing still remains an important cause of school absence and still seems to be undertreated.

Asthma is the commonest chronic illness among schoolchildren and an important cause of absence from school and of reduced participation in sport and other activities. ${ }^{1-5} \mathrm{~A}$ number of studies have suggested that asthma in children is underdiagnosed and undertreated, ${ }^{167}$ and in the two community surveys conducted in the late 1970s about one in 10 children reported that they had wheezed during the previous year, but less than a third of these had been diagnosed as having asthma. When prophylactic treatment was given to a selected group of children with wheezing, school absenteeism was reduced 10 fold. ${ }^{1}$

Because circumstances may have changed after the publicity given to asthma in recent years, we have obtained data on the number of children with wheezing, the number diagnosed as having asthma, the use of drugs to control asthma, and school absence because of wheezing, from a survey of schoolchildren in Nottingham in 1985. Our survey is part of a wider assessment of the management of asthma in primary schools, an area of management that has until recently received little attention. ${ }^{89}$

\section{Subjects and methods}

Twenty nine schools were selected at random from the 116 local education authority primary schools that had responded to a pilot questionnaire survey of Nottingham schools 10 months previously. ${ }^{8}$ The head teacher of each school was visited and asked to participate in the study. They were asked to give the number of children aged 5-11 years on the school roll and the number of children known to have asthma.

A questionnaire with a covering letter and an addressed envelope for the reply was then distributed to the parents of each child in the school by the children. The questionnaire asked for the child's name, sex, and date of birth, a history of wheezing attacks or sudden difficulty with breathing, night cough, bronchitis, prescribed drugs, and the number of days the child was absent from school because of episodes of wheezing during the previous year. Where requested questionnaires were also provided in Urdu (about 400).

Permission for the survey was obtained from the local director of education and the Nottingham City Hospital ethics committee. The director of community child health approved the study, and local family practitioners were informed.

When the questionnaires were analysed, $\beta$ agonists, sodium cromoglycate, oral and inhaled steroids, and methylxanthines were included as drugs being taken for asthma. Days absent from school in the different groups were compared by 
Student's $t$ test, and differences between groups for symptoms, school absence, and drugs prescribed, by Z-test of proportions.

\section{Results}

All but one head teacher agreed to participate. There were 4750 pupils aged 5 to 11 years in the remaining 28 schools, with a mean of 170 pupils/ school (range 60 to 346). Questionnaires were returned for 3805 children $(80 \%)$. The response rate was not related to the size of locality of the school but was lower among Asian families only 55\% of whom replied. Unless otherwise stated the percentage figures given refer to the percentage of respondents.

\section{CHILDREN WITH ASTHMA OR TAKING DRUGS} FOR ASTHMA

Before the survey head teachers knew of $230(4 \cdot 8 \%)$ children with asthma. The parents' questionnaires identified 224 children who had been diagnosed as having asthma ('asthma' group), representing $5.9 \%$ of respondents and $4.7 \%$ of all children in the schools; $155(69 \%)$ were boys. The proportion of children diagnosed as having asthma was similar in each year of birth. Drugs were currently being taken for asthma by $203(91 \%)$ of these children.

An additional $48(1.3 \%)$ children had been prescribed drugs for asthma, though parents did not report that a diagnosis of asthma had been made. Of these children 11 were said to have hay fever or an allergy, and eight 'wheezy bronchitis', 'allergic bronchitis', or 'wheezy cough'.

\section{RESPIRATORY SYMPTOMS}

The prevalence of wheezing was $17.5 \%$ at any time. During the previous year $438(11.5 \%)$ children had had wheezing, one-third had had night cough and $366(9 \cdot 6 \%)$ wheeze and cough. Bronchitis was reported for $194(5 \cdot 1 \%)$ of children though most had had only one attack.

Of the 438 children who reported wheezing at the time of the survey, $206(47 \%)$ had been diagnosed as having asthma, $39(9 \%)$ were receiving drugs for asthma without a diagnosis having been made and $190(43 \%)$ were in neither group, receiving no treatment. The proportion with wheezing in the previous year was similar for each year of birth.

Children diagnosed as having asthma were more likely to have had symptoms in the last year and to have had more severe symptoms than those in the group receiving drugs (93\% compared with $83 \%$ for wheeze, $91 \%$ compared with $75 \%$ for night cough, and $55 \%$ compared with $27 \%$ and $56 \%$ compared with $42 \%$ for five or more episodes of wheeze and night cough, respectively). In the group not receiving treatment, fewer children had wheeze $(17 \%)$ and night cough $(26 \%)$ on five or more occasions.

\section{ABSENCE FROM SCHOOL}

Altogether 265 children (7\%) had been absent from school in the previous year due to episodes of wheezing (table 1). This was more common for children in the asthma group (66\%) than those receiving drugs alone $(46 \%)$, or those receiving no treatment $(51 \%)$. In the group receiving no treatment the symptoms causing absence from school were often attributed to bronchitis, chest infections, or coughs $(61 \%)$.

Precise data for days lost from school were available for 230 children. Median absence was seven days, and varied little among the asthma group (seven days), the group receiving drugs (six and a half days), and the group receiving no treatment (five days). Children with more frequent wheezing and night cough lost more days from

Table 1 Number of days absent from school because of wheeze for children diagnosed or treated for asthma and in children reporting wheeze in the previous year

\begin{tabular}{|c|c|c|c|c|c|c|}
\hline & \multicolumn{5}{|c|}{ Days absent } & \multirow{2}{*}{$\begin{array}{l}\text { Precise No of days } \\
\text { absent unknown }\end{array}$} \\
\hline & None & $1-5$ & $6-10$ & $11-20$ & $>20$ & \\
\hline \multicolumn{7}{|c|}{$\begin{array}{l}\text { Group diagnosed as having } \\
\text { asthma }\end{array}$} \\
\hline $\begin{array}{l}\text { Group rece } \\
\text { asthma } \\
(n=48)\end{array}$ & 26 & 9 & 3 & 4 & 4 & 2 \\
\hline $\begin{array}{c}\text { Group with } \\
\text { diagnosed } \\
\text { treatment } \\
(n=190)\end{array}$ & 94 & 49 & 20 & 9 & 6 & 12 \\
\hline
\end{tabular}


school (table 2). Sixty four (1.7\%) respondents had lost more than 10 days schooling in the last year as a result of wheezing (41, eight, and 15 , respectively in the three groups).

DRUGS BEING TAKEN FOR ASTHMA

At the time of the survey 368 children $(10 \%$ of the respondents) were taking drugs, and $251(68 \%)$ of these were receiving them for asthma. Treatment for asthma was prescribed most often to be taken three or four times a day $(140,56 \%)$, and for the rest once or twice daily $(40,16 \%)$, or as required $(70,28 \%)$.

$\beta$ Agonists had been prescribed to most children $(195,87 \%)$ in the asthma group, and for $117(52 \%)$ children this was the only treatment. The formulations prescribed were almost equally divided between a syrup, a dry powder for inhalation, and a metered dose inhaler. Almost a quarter $(52,23 \%)$ of the children were taking sodium cromoglycate, and a smaller number were taking an inhaled steroid $(36,16 \%)$, or theophylline $(13,6 \%)$. Thirteen

Table 2 School absence and respiratory symptoms in children reporting absence because of wheezing $(n=265)$

\begin{tabular}{lllll}
\hline Symptom & $\begin{array}{l}\text { No of } \\
\text { absences/ } \\
\text { year }\end{array}$ & No (\%) & $\begin{array}{l}\text { No data } \\
(\%)\end{array}$ & $\begin{array}{l}\text { Median } \\
\text { No of } \\
\text { days } \\
\text { absent }\end{array}$ \\
\hline Wheeze: & $<5$ & $143(54)$ & 4 & 5 \\
Night cough: & $>5$ & $122(46)$ & 7 & 10 \\
Wheeze and & $135(51)$ & 3 & 5 \\
cough: & $>5$ & $130(49)$ & 8 & 10 \\
\hline
\end{tabular}

This includes children in whom asthma had been diagnosed and who were receiving treatment. children were using nebulisers, three regularly but only one during school hours. The use of drugs for the treatment of asthma showed a similar pattern in the second group, with 43 of the 48 children taking a $\beta$ agonist alone, three sodium cromoglycate, one an inhaled steroid, and one theophylline orally.

\section{ASSOCIATION BETWEEN RECEIVING TREATMENT,} SYMPTOMS, AND ABSENCE FROM SCHOOL

More than half the children with diagnosed asthma who reported more frequent respiratory symptoms (wheeze, or night cough, or both on five or more occasions) had not been prescribed any drugs, or had been given $\beta$ agonists only (table 3 ). Although fewer of these children had lost time from school because of wheeze than had those taking two or more drugs, some were nevertheless losing a substantial amount of schooling (table 3). Of the 64 children who had lost more than 10 days from school in the previous year because of wheezing, $18(28 \%)$ were receiving no treatment for their asthma, and 27 (42\%) were receiving only $\beta$ agonists; 19 (30\%) were taking prophylactic drugs.

\section{PROVISION OF CARE}

General practitioners had sole care of $171(76 \%)$ of the children in the asthma group; the remainder were attending a hospital outpatient clinic. Those attending hospital were more likely to have frequent episodes of wheezing and to miss school as a consequence of this $(75 \%$ compared with $49 \%$, and $74 \%$ compared with $63 \%$, respectively, $\mathrm{p}<0.05$ in both cases). They were also more likely to be prescribed theophylline ( $18 \%$ compared with $2 \%)$, nebulised drugs ( $19 \%$ compared with $2 \%)$ and more than two drugs in combination $(19 \%$ compared with $5 \%)(p<0.001$ in each case $)$. Median days absence because of wheezing among those reporting absence

Table 3 Respiratory symptoms and school absence, and prescribed medication in children with diagnosed asthma $(n=224)$

\begin{tabular}{|c|c|c|c|c|c|c|}
\hline & 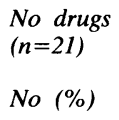 & $\begin{array}{l}\beta \text { Agonists } \\
\text { alone } \\
(n=117) \\
\text { No }(\%)\end{array}$ & $\begin{array}{l}\text { Sodium cromoglycate } \\
\text { alone }(n=5) \\
\text { No }(\%)\end{array}$ & $\begin{array}{l}\beta \text { Agonists and } \\
\text { sodium cromoglycate } \\
(n=38) \\
\text { No }(\%)\end{array}$ & $\begin{array}{l}\beta \text { Agonists and } \\
\text { inhaled steroids } \\
(n=25) \\
\text { No }(\%)\end{array}$ & $\begin{array}{l}\text { More than } \\
\text { two drugs } \\
(n=18) \\
\text { No }(\%)\end{array}$ \\
\hline \multicolumn{7}{|l|}{ Symptoms* } \\
\hline Wheeze $>5 \quad(n=123)$ & $7(6)$ & $56(45)$ & $3(2)$ & $24(20)$ & $19(15)$ & $14(11)$ \\
\hline Night cough $>5(n=126)$ & $13(10)$ & $58(46)$ & $2(2)$ & $22(17)$ & 15 (12) & $16(13)$ \\
\hline $\begin{array}{l}\text { Wheeze and cough }>5 \\
(n=100)\end{array}$ & & & & & & \\
\hline $\begin{array}{l}(n=100) \\
\text { Bronchitis }>5 \quad(n=27)\end{array}$ & $6(6)$ & $47(47)$ & 0 & $20(20)$ & $14(14)$ & $13(13)$ \\
\hline Bronchitis >5 $(n=27)$ & $3(11)$ & $10(37)$ & 0 & $7(26)$ & $2(7)$ & $5(19)$ \\
\hline \multicolumn{7}{|l|}{ School absence: } \\
\hline No of subjects & 6 & 74 & 3 & 29 & 19 & 16 \\
\hline $\begin{array}{l}\text { Median days lost from } \\
\text { school }\end{array}$ & 14 & 7 & $1 \cdot 5$ & $8 \cdot 5$ & $8 \cdot 5$ & $15 \cdot 5$ \\
\hline
\end{tabular}

${ }^{*}$ The first three groups of symptoms (wheeze, night cough, and wheeze and cough) are not mutually exclusive. 
was 10 days for those attending hospital and seven days for those attending general practitioners.

\section{Discussion}

In this survey of primary schoolchildren in Nottingham the prevalence of wheezing in the last year among respondents was $11.5 \%$ with $5.9 \%$ reporting a diagnosis of asthma. A further $1.3 \%$ of respondents had been prescribed drugs for the treatment of asthma without apparently having been given a diagnosis of asthma.

The response rate of $80 \%$ was smaller than that seen in some previous surveys using a similar method of data collection. ${ }^{161011}$ This was partly because, at the head teachers' request, we did not send reminders to those who did not respond. We have no information on the reasons for nonresponse or the extent to which this biased our results. Omission of data about children who were away because of asthma at the time of the survey would cause our figures to underestimate the true prevalence, whereas an increased response from parents with children with chest problems would bias the findings in the opposite direction. The figures expressed as a percentage of all the children in the schools give a minimum prevalence value of $9.2 \%$ for wheezing in the previous year and $4.9 \%$ for diagnosed asthma.

A number of workers have tried to estimate the prevalence of asthma among children, though methods of data collection and the population selected for the survey have varied (table 4). The figures for the prevalence of diagnosed asthma obtained in four community based studies in the 1960s (in which parents and children were interviewed) were much lower $(2 \cdot 3 \% \text { to } 4 \cdot 8 \%)^{2} 12-14$ than those obtained from three surveys in general practice $(7 \cdot 8 \%$ to $11 \%) .{ }^{15-17}$ These differences may reflect the particular interests of the authors in the surveys in general practice, or a discrepancy between the doctor's diagnosis of asthma, and parents knowledge of or reporting of the diagnosis. In studies of random populations of schoolchildren in the 1970s in north Tyneside, Croydon, Newcastle, and Cardiff ${ }^{161011}$ the prevalence of episodic wheezing in the last year varied from $9.3 \%$ to $12.4 \%$, and our finding of $11.5 \%$ is similar. The prevalence of diagnosed asthma in these studies was much lower (being between $1.3 \%$ and $4 \%$ ) and lower than the figure of $5.9 \%$ obtained in the present survey and that of $5 \%$ obtained in a survey of schoolchildren in south London in $1985 .{ }^{18}$

There was some variability in age and in the methods used in these studies (table 4), and this may account for some of the differences in the prevalence of diagnosed asthma, but the size of the difference suggests that there is now an increased willingness to use the diagnostic label of asthma in wheezy children. This may be due to the increased publicity about asthma in recent years, although local factors such as the interests of local physicians

Table 4 Comparison of asthma prevalence studies in children

\begin{tabular}{|c|c|c|c|c|c|c|c|}
\hline First author & Place & $\begin{array}{l}\text { Year that } \\
\text { survey was } \\
\text { carried out }\end{array}$ & $\begin{array}{l}\text { Age of } \\
\text { children } \\
\text { (years) }\end{array}$ & $\begin{array}{l}\text { No of } \\
\text { children } \\
\text { studied }\end{array}$ & $\begin{array}{l}\text { Response } \\
\text { rate }(\%)\end{array}$ & $\begin{array}{l}\text { Episodes of } \\
\text { wheezing in } \\
\text { previous } \\
\text { year (\%) }\end{array}$ & $\begin{array}{l}\% \text { Diagnosed } \\
\text { as having } \\
\text { asthma }\end{array}$ \\
\hline \multicolumn{8}{|c|}{ Interviews with parents and children: } \\
\hline $\begin{array}{l}\text { Mitchell and Dawson }{ }^{2} \\
\text { Graham et al }{ }^{12} \\
\text { Peckham and Butler }{ }^{13} \\
\text { Morrison-Smith et } a l^{14}\end{array}$ & $\begin{array}{l}\text { Aberdeen } \\
\text { Isle of White } \\
\text { National } \\
\text { Birmingham }\end{array}$ & $\begin{array}{l}1964 \\
1967 \\
1969 \\
1968-9\end{array}$ & $\begin{array}{l}10-15 \\
9-11 \\
11 \\
5-18\end{array}$ & $\begin{array}{r}2743 \\
3300 \\
13509 \\
20958\end{array}$ & $\frac{92}{-}$ & $\frac{-}{-}$ & $\begin{array}{l}4 \cdot 8 \\
2 \cdot 3 \\
3 \cdot 5 \\
4 \cdot 2\end{array}$ \\
\hline \multicolumn{8}{|c|}{ General practitioners' records: } \\
\hline $\begin{array}{l}\text { Levy and Bell }{ }^{15} \\
\text { Heijne Den Bak }{ }^{16} \\
\text { Toop }\end{array}$ & $\begin{array}{l}\text { Middlesex } \\
\text { West Cumbria } \\
\text { Edinburgh }\end{array}$ & $\begin{array}{l}1983 \\
1983 \\
1983\end{array}$ & $\begin{array}{c}1-11 \\
<16 \\
7\end{array}$ & $\begin{array}{l}470 \\
655 \\
214\end{array}$ & - & $\frac{-}{-}$ & $\begin{array}{l}11 \\
7 \cdot 8 \\
8\end{array}$ \\
\hline
\end{tabular}

${ }^{*}(I)=$ subsample interviewed. 
may influence the findings in individual areas. The fact that the prevalence of wheezing has remained fairly consistent over a period of 12 years (19731985) does not support the suggestion that the prevalence of asthma is increasing. ${ }^{19}$

Although our data suggest that wheezy children are more likely to be diagnosed as having asthma, they also suggest that undertreatment is still common. We identified 96 children $(2.5 \%$ of respondents) in whom wheezing was sufficiently troublesome for them to lose time from school but who were receiving no medication for asthma. It would seem likely from the experience in north Tyneside ${ }^{1}$ that some if not most of these children have asthma and would benefit from specific treatment.

Altogether 265 of our respondents had lost time from school as a result of wheezing, the median time lost being seven days a year. This figure may be an underestimate because precise data were not available for 34 children, their parents quantifying the days lost as 'numerous' or 'lots'. Speight et al found that when parents were interviewed they tended to underestimate their child's absence when this was validated against school records. Of the children in our study with wheeze in the previous year at least $16 \%$ had lost more than 10 days from school and at least $6 \%$ more than 20 days. These figures seem to represent an improvement on those found in previous surveys, although direct comparisons are difficult because of different response rates, methods of measuring absence from school, and the selection of children. In north Tyneside $34 \%$ of 7 year old children reporting wheeze had lost over 50 days in their first three school years, and in Croydon $12 \%$ of wheezy 9 year old children had lost more than 30 days in the last year. School absence is a fairly crude measure of the morbidity encountered by these children. Poor control of asthma with disturbed nights or exercise induced wheezing can result in suboptimal academic performance or lack of participation in sports without necessarily loss of time from school. Restrictions on educational, social, and physical activities are more difficult to determine.

Drugs prescribed for asthma accounted for two thirds of all drugs taken by Nottingham schoolchildren. $\beta$ Agonists were prescribed most often, to $56 \%$ of children with wheeze in the last year and to $6 \%$ of all children. These figures are similar to those in a recent survey in Sussex primary schoolchildren, ${ }^{9}$ in which $5 \%$ were using bronchodilator inhalers. Prophylactic drugs (sodium cromoglycate or inhaled steroids) had been prescribed to $20 \%$ of children with wheeze in the last year compared with $10 \%$ of the children in north Tyneside. ${ }^{1}$

Treatment for asthma can be fairly complicated for young children and some were receiving more than one type of drug or inhaler, often with different indications for use (for example, for prophylaxis or relief). Most drugs ( $84 \%$ ) were prescribed to be taken four or six hourly or as required and hence needed to be taken or be available during school hours. Many children have difficulty in using inhalers correctly ${ }^{9}$ and some will ask teachers for help and advice, though teachers are often ill prepared for this task. ${ }^{20}$

Asthma and wheezing continue to be important problems for both schoolchildren and schools. In this study one child in 15 had missed school in the last year because of wheezing and one in 20 was bringing drugs for the treatment of asthma to school. Our results suggest that asthma is diagnosed more often now than in the past but many children still seem to have asthma that is undiagnosed or inadequately treated. Of the 64 children who had lost more than 10 days from school becasue of wheezing $70 \%$ were receiving no treatment or only $\beta$ agonists. These children would almost certainly benefit from a more aggressive policy towards diagnosis and treatment, though this requires confirmation.

We are grateful to Dr EJ Hiller and Dr E More for their advice and support, and to Dr John Britton for his help with the manuscript.

\section{References}

1 Speight ANP, Lee DA, Hay EN. Underdiagnosis and undertreatment of asthma in childhood. Br Med J 1983;286:1253-7.

2 Mitchell R, Dawson M. Educational and social characteristics of children with asthma. Arch Dis Child 1973;48:467-71.

${ }^{3}$ Freudenberg N, Feldman CH, Clark NM, Millman EJ, Valle I, Wasilewski $\mathrm{Y}$. The impact of bronchial asthma on school attendance and performance. $J$ Sch Health 1980;50:522-6.

${ }^{4}$ Bremberg SG, Kjellman NIM. Children with asthma: how do they get along at school? Acta Paediatr Scand 1985;74:833-40.

5 Richards W. Asthma, allergy and school problems. J Sch Health 1986;56:151-2.

${ }^{6}$ Anderson HR, Bailey PA, Cooper JC, West S. Morbidity and school absence caused by asthma and wheezing illness. Arch Dis Child 1983;58:777-84.

7 Conway SP, Littlewood JM. Admission to hospital with asthma. Arch Dis Child 1985;60:636-9.

${ }^{8}$ Hill RA, Britton JR, Tattersfield AE. Management of asthma in schools. Arch Dis Child 1987;62:414-5.

${ }^{9}$ Storr J, Barrell E, Lenney W. Asthma in primary schools. $\mathrm{Br}$ Med $J$ 1987;295:251-2.

${ }^{10}$ Colver AF. Community campaign against asthma. Arch Dis Child 1984;59:449-52.

11 Burr ML, Eldridge BA, Borysiewicz LK. Peak expiratory rates before and after exercise in schoolchildren. Arch Dis Child 1974;49:923-6.

12 Graham PJ, Rutter ML, Yule W, Pless IB. Childhood asthma: a psychosomatic disorder? Some epidemiological considerations. British Journal of Preventive and Social Medicine 1967;21:78-85.

${ }_{13}$ Peckham C, Butler N. A national study of asthma in childhood. J Epidemiol Community Health 1978;32:79-85.

14 Morrison-Smith J, Harding LK, Cumming G. The changing prevalence of asthma in schoolchildren. Clin Allergy 1971;1: $57-61$. 
15 Levy M, Bell L. General practice audit of asthma in childhood. Br Med J 1984;289:1115-6.

${ }^{16}$ Heijne Den Bak J. Prevalence and management of asthma in children under 16 in one practice. Br Med $J$ 1986;292:175-6.

17 Toop LJ. Active approach to recognising asthma in General Practice. Br Med J 1985;290:1629-31.

18 Johnston IDA, Bland JM, Anderson HR. Ethnic variation in respiratory morbidity and lung function in childhood. Thorax 1987;42:542-8.
19 Fleming DM, Crombie DL. Prevalence of asthma and hay fever in England and Wales. Br Med $J$ 1987;294:279-83.

${ }^{20}$ Hill RA, Tattersfield AE. The role of primary schoolteachers in the supervision of childhood asthma. Thorax 1986;41:707.

Correspondence to Ms R Hill, Respiratory Medicine Unit, City Hospital, Auckland Road, Nottingham NG5 1PB.

Accepted 1 September 1988 